žurnalistiky, politologie, ale i sociologie, pedagogiky etc., tedy aby se monografie stala rovněž užitečnou studijní pomůckou. Je zřejmé, že absolutizace jakékoliv metody, tedy i metody kontrastivně imagologické, by mohla být zneužita $\mathrm{k}$ cílům, před nimiž kniha varuje, tedy k ideologizaci („západní“ kultura je vyšší, protože před stereotypy varuje a odhaluje je, ukazuje tak svoji prevalenci před kulturou „východní, ocitající se v zajetí autostereotypů neschopných sebereflexe), to je však nebezpečí aktuální nejen pro tuto metodologickou oblast a nic neubírá badatelskému týmu na záslužném a užitečném díle. Na díle, které by mělo být přeloženo minimálně do angličtiny, a na záslužném projektu, který by neměl být uzavřen jen jedním výstupem.

Alexej Mikulášek

\title{
Literatura:
}

ZELENKA, M. - TKÁČ-ZABÁKOVÁ, L. (eds): Imagológia ako výskum obrazov kultúry: $K$ reflexii etnických stereotypov krajín $V_{4}$. Nitra: Univerzita Konštantína Filozofa, 2018, 162 s. ISBN 978-80-558-1294-6.

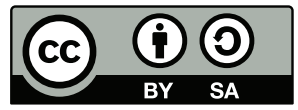

Toto dílo Ize užít v souladu s licenčními podmínkami Creative Commons BY-SA 4.0 International (<https:// creativecommons.org/licenses/by-sa/4.0/legalcode>). Uvedené se nevztahuje na díla či prvky (např. obrazovou či fotografickou dokumentaci), které jsou v díle užity na základě smluvní licence nebo výjimky či omezení príslušných práv.

https://doi.org/10.5817/OS2020-3-10

\section{Творческое путешествие И. Ильфа}

ПОЗДНЯКОВ, К. С.: Возвращение в Одессу. Проза И. А. Ильфа. Самара: АНО «Издательство СНЦ», 2018. 128 с. ISBN 978-5-6042205-2-8.

Современное состояние российского литературоведения и удаленность настоящего времени от эпохи, когда творил И.Ильф, позволили нашему современнику К. С. Позднякову создать увлекательную монографию, в историко-литературном аспекте исследующую творчество данного мастера слова.

Поэтика прозы И. Ильфа анализируется в широком контексте русской и зарубежной литературы: описаны и убедительно охарактеризованы преемственность художественного высказывания названного писателя традициям Н. Гоголя, Ф. Достоевского, Ч. Диккенса, А. Конан Дойла. К. С. Поздняков выявляет творческий диалог И. Ильфа со своими современниками М. Зощенко, 
М. Булгаковым, Ю. Олешей, И. Бабелем, Е. Зозулей, В. Маяковским, Д. Хармсом и др.

Монография выполнена в лапидарном стиле, составляет всего 128 страниц. Однако концентрированная подача фактов позволяет автору донести до читателя значительный объем информации, можно говорить о значительной информационной загруженности рецензируемой монографии.

К. С. Поздняков распределяет творчество И. Ильфа на три периода: 1923-1924 гг., период поиска оригинального художественного высказывания; 1924-1926 гг., период освоения художественно-публицистических жанров журналистики; 1927-1930 гг., работа в соавторстве с Е.Петровым. Ученый полагает, что последние годы жизни И.Ильфа (1931-1937) тесно примыкают к третьему периоду ${ }^{1}$, это время, когда начинается постепенное расхождение соавторов. В те годы «круг в творческом путешествии И. А. Ильфа замкнулся» ${ }^{2}$. Мастер слова в набросках нового романа вернулся в пространство родного города Одессы, обращаясь к узнаваемому речевому жанру, неожиданным сюжетным поворотам.

Структура монографии соотносится с периодизацией: в каждой главе раскрыты особенности, ведущие черты того или иного периода, всего 4 главы. Последняя - посвящена творчеству последних лет жизни писателя, сопоставлению соцреалистических опытов соавторов и планов И. Ильфа из «Записных книжек». Каждая глава предваряется аннотацией, результирующей содержание. Библиографический список соответствует лапидарному стилю, не поражает читателя изобилием. Автор подает научную информацию, снабжая немногочисленными постраничными ссылками. Литературоведческие обобщения даются описательным образом и не перегружают научный текст. При этом очевидно, что подобные обобщения автор осуществляет на основе исчерпывающих знаний литературного процесса, биографических фактов И. Ильфа и его окружения; очевидна уверенная ориентация К. С. Позднякова в море литературных направлений и фактов 20-х-30-х гг. ХХ вв.

В монографии по-современному, без установки на аксиологию характеризуются художественный метод социалистического реализма в литературном процессе первой четверти XX вв., особенности творческого тандема И. Ильфа и Е. Петрова с учетом сильных сторон творческой организации каждого из соавторов. К. С. Поздняков опровергает сложившийся в российском «литературоведении общепринятый подход к творчеству И. А. Ильфа и Е. Петрова: до

1 POZDNJAKOV, K. S.: Vozvraščenije v Odessu. Proza I. A. Il'fa. Samara: ANO «Izdatel'stvo SNC», 2018, s. 7 .

2 Ibidem. 
дилогии ничего весомого авторами по отдельности создано не было», а также «соображение о второстепенности, некой неполноценности самостоятельного творчества каждого из авторов» ${ }^{3}$.

Характеризуя поэтику прозы И. Ильфа, ученый определяет ведущие черты творчества, среди которых называет: креативность (склонность к языковой игре, созданию каламбуров, ориентация на одесский юмор и проч.), пессимизм $^{4}$. Характеризуемые К.С.Поздняковым темы творчества И.Ильфа ярко определяют обстановку и время создания произведений мастера слова; таковы, например, коммунализация страны, инициация провинциала, тема страха. Названные темы предопределили создание характерных образов: образ коммунального пространства ${ }^{5}$; образ многофункционального работника ${ }^{6}$, образ обывателей, названных «непугаными идиотами» ${ }^{7}$. Последний образ возник как литературная перекличка с произведением М. Пришвина «В краю непуганых птиц. Онего-Беломорский край». Отметим, что данное выражение И. Ильфа закрепилось в русском дискурсе и фиксируется «Энциклопедическим словарем крылатых слов и выражений» В. В. Серова ${ }^{8}$.

В монографии значительное внимание уделено средствам выразительности, формирующим поэтику прозы И. Ильфа, - тропам и фигурам речи. С литературоведческих позиций характеризуются свойственные идиостилю писателя оригинальные метафоры, показаны употребления приема метонимии и синекдохи ${ }^{9}$, сравнения ${ }^{10}$, ирония ${ }^{11}$, каламбур. К. С. Поздняков отмечает, что творчеству И. Ильфа характерны интертекстуальные отсылки. В монографии анализируются штампы советской эпохи, употребленные в ироническом ключе, особенности применения синонимов, специфика антропонимии И. Ильфа и творческого тандема с Е. Петровым, например ${ }^{12}$; исследуется применение новояза в характерологической функции. По всему тексту монографии прослеживается внимание К. С. Позднякова к библейскому

3 Ibidem, s. 4.

4 Ibidem, s. 59 и др.

5 Ibidem, s. 105 и др.

6 Ibidem, s. 84 и др.

7 Ibidem, s. 82 и др.

8 SEROV, V. V. Ėnciklopedičeskij slovar' krylatych slov i vyraženij. Moskva: OOO Izdatel'stvo «Lokid-Press», 2005.

9 POZDNJAKOV, K. S.: Vozvraščenije v Odessu. Proza I. A. Il'fa. Samara: ANO «Izdatel'stvo SNC», 2018, s. 22 i dr.

10 Ibidem.

11 Ibidem, s. 99 и др.

12 Ibidem, s. 68. 
слову в творчестве И. Ильфа, например $\left.{ }^{13}\right)$; показано ироническое и пародийное переосмысление библейских сюжетов, имен и проч.

Особым достоинством рецензируемой монографии следует назвать обращение ученого к произведениям автора, ранее не исследовавшимся в литературоведении; подробно рассмотрены фрагменты и наброски незавершенных произведений.

В целом, монографию К. С. Позднякова можно считать свежим, актуальным исследованием поэтики прозы И. Ильфа в историко-литературном аспекте. Такое исследование будет интересным самому широкому кругу читателей: специалистам-филологам, аспирантам и студентам, всем любителям хорошего русского слова.

Елена Павловна Иванян

\section{Библиография:}

POZDNJAKOV, K. S.: Vozvraščenije v Odessu. Proza I. A. Il'fa. Samara: ANO «Izdatel'stvo SNC», 2018, 128 s. ISBN 978-5-6042205-2-8.

SEROV, V. V. Ėnciklopedičeskij slovar' krylatych slov i vyraženij. Moskva: OOO Izdatel'stvo «Lokid-Press», 2005, 677 s. ISBN 5-320-00323-4.

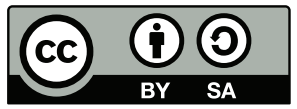

This work can be used in accordance with the Creative Commons BY-SA 4.0 International license terms and conditions (/https://creativecommons.org/licenses/by-sa/4.0/legalcode>). This does not apply to works or elements (such as images or photographs) that are used in the work under a contractual license or exception or limitation to relevant rights.

\section{O význame a hodnote (literárnohistorického) vedenia a poznania}

TATÁR, J.: Umelecký profil Štefana Krčméryho. Banská Bystrica: Belianum, 2015. 105 s. ISBN 978-80-557-0949-9.

Do prirodzenej výbavy literárnovedného výskumu patrí latentné obnovovanie vývinovo obsažných javov, ktoré sa svojou aktuálnost’ou či akútnostou prirodzene posúvajú v čase a sú navrstvované, znova prirodzene, novými reáliami, osobnostami,

13 Ibidem, s. 36-37. 